\title{
THE ANNAIS
}

$\triangle$ ND

\section{MAGAZINE OF NATURAL HISTORY. \\ [EIGHTH SERIES.]}

No. 70. OCTOBER 1913.

XXXIX.-Descriptions of new Species of Staphylinidæ from the West Indies. By Malcolm Cameron, M.B., R.N., F.E.S.

\section{Part I.}

\section{I S P I N I.}

1. Lispinus claviger, sp. $\mathrm{n}$.

(Fauvel, in litt.)

Black, shining; thorax and elytra red; antennæ and legs, posterior margins of first four visible abdominal segments narrowly, the penultimate broadly, and the last entirely reddish testaceous.

Length $2 \mathrm{~mm}$.

Size of L. nigrifrons, Fvl,, but the much less depressed form, more shining, differently coloured, distinctly but sparingly punctured thorax, and the very slight groundsculpture of the fore parts readily distinguish it.

Head black, slightly rufescent in front, with a wellmarked fovea on either side between the eyes, feebly and sparingly punctured, with a fine transverse strigose groundsculpture and a few fine setæ. Antennæ pilose, with the first three joints gradually decreasing in length; fourth and fifth about as long as broad; sixth small, transverse; seventh to tenth much more strongly transverse; eleventh short, oval. Thorax distinctly transverse, as wide as the elytra, the sides slightly rounded in front, the basal third narrowed in a Ann. \& Mag. N. Hist. Ser. 8. Vol. xii. 
straight line to the posterior angles, which are obtuse, impressed on either side before the base; puncturation rather large, sparing, and scattered; ground-sculpture strigose, feeble. Elytra longer than the thorax, a little longer than broad, parallel, with distinct sutural stria, internal to which is a row of four or five punctures and externally two setigerous pores; the disc with a very few, very fine obsolete punctures and scarcely perceptible ground-sculpture. Scutellum transversely strigose, with a few marginal punctures. Abdomen with sparing, more or less erect, yellow pubescence and distinct ground-sculpture forming a scaly pattern.

St. Vincent $(H . H$. Smith). Type in the British Museum.

\section{Lispinus impar, sp. n.}

(Fauvel, in litt.)

Entirely red; head sometimes darker, shining, sparingly punctured; ground-sculpture rather feeble. Antennæ and legs reddish testaceous.

Length $2.5-2.8 \mathrm{~mm}$.

In size and general appearance similar to L. fauveli, Shp., especially to the immature reddish forms. The thorax is, however, a little shorter, more abruptly narrowed before the posterior angles; the ground-sculpture is much less distinct throughout, and on the thorax forms longitudinal meshes.

Head large, a little narrower than the thorax, foveolate in front on either side, finely and sparingly punctured; groundsculpture coriaceous. Antennæ with first joint rather stout, a little longer than second; third, fourth, and fifth longer than broad and scarcely differing in length; sixth to tenth transverse, gradually increasing in width, pilose. Thorax distinctly transverse, about one and a haif times as broad as long, broadest in front of the middle, gradually narrowed anteriorly, rather abruptly narrowed at the base before the slightly obtuse posterior angles; disc with smooth impunctate central line, longitudinally impressed on either side, the impression reaching from within the posterior angles forwards for fully half the length, finely and sparingly punctured on the disc, almost impunctate at the sides, with a fine longitudinal strigose ground-sculpture; sides with four or five setæ. Scutellum impunctate. Elytra more than half as long again as the thorax, distinctly longer than broad, sides with two or three setæ; pretty deeply impressed at the base internal to the humeral angles, and with two setigerous pores, one near the suture posteriorly and one in front and external ; puncturation very fine and very sparing; ground- 
sculpture longitudinally strigose. Abdomen with very few punctures, pubescence more or less erect, sparing ; groundsculpture distinct, reticulate.

St. Vincent (H. H. Smith). Type in the British Museum.

TH OR A C O P H O R I.

3. Thoracophorus guadalupensis, sp. n.

(Fauvel, in litt.)

Very small, narrow, dull, reddish brown, with head darker. Antennæ and legs reddish testaceous.

Length $1.8 \mathrm{~mm}$.

In general appearance and form of thorax very near T. pallidus, Shp., but differs in the darker colour, more robust build, and shorter elytra.

Head pitchy black, suborbicular, with four longitudinal carinæ; eyes small, visible from above; temples very small, angular. Antennæ reddish testaceous; first and second joints dilated, of about equal length ; third much narrower than the second, but of equal length; fourth to sixth of equal length and breadth, as long as broad; seventh larger than the sixth, as long as broad; eighth to tenth transverse; eleventh shortly oval, Thorax transverse, quite a third broader than long, broader between the anterior than the posterior angles; sides gradually converging posteriorly, finely crenulate, emarginate before the rectangular posterior angles; anterior angles almost rectangular; disc with four distinct longitudinal carinæ, the two central bounding on each side a median elevated part (which shows traces of two short parallel carinulæ), the two lateral elose to and nearly parallel with the sides. Elytra nearly a third longer than the thorax, a little transverse, each with five longitudinal carinæ, the intervals concave. Sculpture of all the fore parts coriaceous. Abdomen gradually pointed, finely coriaceous, very finely and sparingly punctured and pubescent.

Grenada $(H, H$. Smith); Haiti. Type in the British Museum.

\section{OXYTELI.}

\section{Trogophlceus (Carpalimus) smithi, sp. n,}

(Fauvel, in litt.)

Black, shining ; thorax cordate, with semilunar impression before the base and a small impression on either side of the 
disc. First joint of antennæ and legs yellow; elytra dark brown.

Length $3 \mathrm{~mm}$.

Very near T. centralis, Shp., from which it differs by the finer and uniform puncturation of the thorax and the finer puncturation of the elytra. From T. croceipes, Fvl., it differs by the much narrower head and thorax, much more coarsely punctured and more even elytra, and the yellow legs and first antennal joint.

Head rather large, narrower than the thorax ; eyes large, their diameter greater than the length of the temples; longitudinally impressed on either side in front, closely and distinctly punctured. Antennæ with exception of the first joint dark; the second a little shorter than third; third to eighth longer than broad, gradually decreasing in length; ninth and tenth about as long as broad; eleventh oval, pointed. Maxillary palpi brown. Thorax transverse, cordate, narrower than the elytra, dilated and rounded in front and narrowed behind; anterior angles completely effaced; disc with a distinct fovea on either side of the middle line and a semilunar impression before the base; puncturation as on head, uniform. Elytra quite one-third longer than the thorax, as long as broad, with an oblique impression between the shoulder and suture; puncturation as of thorax, evanescent towards the postero-external angles. Abdomen finely and rather closely punctured and pubescent.

Grenada $(H . H$. Smith). Type in the British Museum.

\section{TH I N OBI I.}

\section{Thinobius miricornis, sp. $\mathrm{n}$.}

(Fauvel, in litt.)

Pitch-black or pitch-brown; the thorax, base of abdomen, legs, first and last three joints of antennæ yellow, sometimes the latter entirely yellow.

Length $1 \cdot 3 \mathrm{~mm}$.

Head narrower than the thorax, transverse, with transverse impressed line between the antennal tubercles; eyes rather small, their diameter about equalling the length of the temples; sculpture close, rugulose. Antennæ ( $\delta$ ) more elongate than in $q$; first joint stout, second shorter than third, fourth to tenth much longer than broad, eleventh a little longer than tenth; in of fourth to sixth joints about twice as long as broad, seventh and eighth a little longer than broad, ninth and tenth as broad as long, eleventh 
elongate, nearly as long as the two preceding together. Mouth-parts yellow. Thorax strongly transverse, more than half as broad again as long, almost semicircular, widest in front; sides evenly rounded from base to anterior angles, which are slightly obtuse, posterior angles effaced; disc rather broadly and deeply impressed in its whole length in middle line in $\delta$, less distinctly or not at all in $q$. Sculpture as on the head. Scutellum yellow. Elytra broader than the thorax and twice its length, scarcely broader than long, with fine rugulose sculpture. Abdomen closely and finely punctured and pubescent, a little more sparingly behind. Museum.

St. Vincent, Grenada (H. H. Smith). Type in British

\section{O s O R I I.}

6. Holotrochus smithi, sp. n.

(Fauvel, in litt.)

Black, shining ; posterior margins of abdominal segments, legs, and antennæ reddish testaceous; margins of thorax and elytra sometimes obscurely red.

Length 3.3-3.5 mm.

Very similar to H. marginatus, Shp., in size and general appearance; but distinguished from it by the longer thorax, not bordered at the base, the fine but distinct reticulate ground-sculpture, and the finer and more obsolete puncturation of the head and thorax, and the impunctate shagreened scutellum. From H. minor, Fvl., it differs by its larger size, the ground-sculpture, and much finer and more obsolete puncturation of the head and thorax, and impunctate shagreened scutellum; and from H.cylindrus, Er., by its shorter and broader thorax and elytra, more distinct groundsculpture of both the latter, and the impunctate shagreened scutellum.

Head narrower than the thorax, truncate anteriorly, very finely and very sparingly punctured, with a fine reticulate ground-sculpture. Antennæ with the first joint stout, second as long as, but stouter than third, fourth and fifth globose ; fifth slightly, sixth to tenth more strongly transverse. Thorax about a third broader than long, a little wider at the anterior angles, very gradually and slightly narrowed behind. Sculpture as on head. Elytra as long as, but narrower than, the thorax, transverse, without visible puncturation, but obsoletely shagreened. Abdomen impunctate, shagreened.

St. Vincent (H. H. Smith). Type in the British Museum. 


\section{Osorius fauveli, sp. $\mathrm{n}$.}

Black, shining; elytra red; antennæ, legs, and posterior margins of the abdominal segments narrowly reddish testaceous. Head, thorax, and elytra moderately coarsely, hut not very closely, punctured. Abdomen with sparse superficial puncturation.

Length $3 \mathrm{~mm}$.

From the description should be placed near O. eggersi, Bernh., from which it differs in colour, absence of impunctate space on the head, the transverse thorax deeply foveolate in front of the posterior angles, the elytra longer than the thorax, and the sparing superficial puncturation of the abdomen.

Head narrower than the thorax, truncate in front, with scattered umbilicate puncturation and coriaceous groundsculpture, without a smooth central line. Antennæ with fourth to tenth joints transverse, gradually increasing in breadth; mouth-parts yellow. Thorax a little broader than the elytra, a little broader than long; sides almost paralle] for four-fifths of their length, then suddenly contracted to the nearly rectangular posterior angles, with a deep rounded fovea in front of the latter, and with rather large, scattered, superficial, umbilicate puncturation, and with a smooth central line; ground-sculpture distinct, coriaceous ; pubescence rather long, coarse, and sparing. Elytra a little longer than the thorax, as long as broad, with puncturation, groundsculpture, and pubescence similar to that of the thorax. Abdomen with very sparing and still more superficial puncturation, and similar ground-sculpture to the elytra; pubescence long, coarse, and sparing.

Haiti. Type in my collection.

\section{MEGA L O P I N I.}

\section{Megalops leviventris, sp. n.}

(Fauvel, in litt.)

Black, shining; thorax with four more or less transverse grooves on either side; each elytron with well-marked humeral callus, behind and internal to which is an impression bearing three to five large punctures grouped irregularly; between the impression and the suture a rounded elevation or callus, and between the impression and the posterior margin a small puncture. Legs and antennæ 
reddish testaceous, the club of the latter infuscate; fourth tarsal joint simple.

Length $3 \cdot 5-4 \mathrm{~mm}$.

A bout the size of $M$. incultus, Shp., but very different by the much smaller head and eyes, less strongly grooved thorax, and the punctured impression on the elytra.

Head, with eyes, large, transverse, almost as broad as the elytra; clypeal spines short, not very distinct; front entirely occupied by a horseshoe-shaped impression, concave backwards, the bottom coarsely and deeply punctured, the smooth space enclosed by it carrying a curved row of three punctures, concave forwards; vertex with a fine, short, raised line in the middle ; mandibles red. Antennæ reddish testaceous, the last two joints brown; first joint concealed, second moderately long and stout, third considerably longer than second and much more slender, fourth to sixth each a little longer than broad, seventh as broad as long; eighth to tenth transverse, the last of them much broader than the ninth ; eleventh oval, pointed. Thorax widest at the middle, its sides evenly rounded, about as long as broad, marked with four more or less transverse furrows on each side; the first, impunctate, follows the anterior margin, disappearing on the disc; the second is deeper, with three large punctures on either side and one on middle of the disc ; the third, also deep and punctured, does not extend across the disc, but is bounded by a large deep puncture on either side of the middle line; the fourth is narrow, follows the posterior border of the thorax, is not interrupted, and is obscurely punctured. Elytra as long as, but broader than, the thorax, transverse; humeral callus well marked, as is also another boss or callus at the base near the suture, base depressed between the calli and with one or two small punctures. External to the sutural callus is an impression containing a group of three to five large punctures, and between this and the posterior margin is a small puncture. Sutural stria distinct, impunctate. Abdomen impunctate, each segment except the last with a short narrow impression at the base on each side.

No sexual differences observed.

Grenada (H. H. Smith). Type in British Museum.

\section{Megalops humeralis, sp. n.}

(Fauvel, in litt.)

Black, shining; elytra yellow, with humeral callus, base, and apex narrowly black; disc with short, deep, punctured 
stria. Legs and antennæ (except last two joints, which are fuscous) reddish testaceous. Tarsi simple.

Length $4 \mathrm{~mm}$.

Narrower and less robust than the smallest specimens of M. punctatus, Er., and the elytra nearly entirely testaceous.

Head and antennæ much as in the preceding species; thorax a little longer than broad, a little wider in the middle, equally narrowed in front and behind, with the sides evenly rounded, narrower than the head and the elytra, and with four coarsely punctured transverse impressions on each side, the first separated from each other by a narrow smooth space on middle of the disc; the second are separated by a broader space bearing a large puncture, the third by a wider impunctate space, the fourth follow the posterior margin and are not interrupted. Elytra about as long as the thorax, scarcely transverse, testaceous; the humeral callus and base narrowly black, the apical margin narrowly and irregularly blackish; sutural callus, sutural stria, and short punctate stria on the disc well marked. Abdomen as in preceding.

St. Vincent (H. H. Smith). Type in the British Museum.

\section{Megalops smithi, sp. n.}

(Fauvel, in litt.)

Blue-black, shining; elytra lemon-yellow, with humeral callus; base, suture, sides, and apical margins narrowly reddish brown, without trace of impression or striæ on the disc. Legs and antennæ (except last two joints, which are brown) reddish testaceous. Tarsi simple.

Length $3.5 \mathrm{~mm}$.

Head with eyes broader than the elytra; clypeal spines long, brownish; mandibles reddish. Antennæ much longer than in the preceding; first joint concealed, second twice as long as broad, third twice as long as second, fourth to eighth longer than broad, gradually decreasing in length; ninth and tenth transverse, especially the tenth; elerenth oval, pointed; front with circular punctate impression, enclosing a smooth, round, central, raised space ; vertex with narrow longitudinal raised line. Thorax (viewed from above) nearly cylindrical, with a small blunt tooth on each side behind the second furrow, a little longer than broad, with four transverse punctured furrows ; the first, not interrupted in the middle line, follows the anterior margin; the second is very narrowly interrupted by a feeble longitudinal ridge ; third distinctly interrupted by a smooth space; fourth follows the posterior margin and is not interrupted. Elytra 
broader than the thorax, widest in the middle, scarcely as long as the thorax, transverse ; humeral callus well marked, sutural callus absent, sutural stria distinct; no trace of discal stria or impression; lemon-yellow, with humeral callus, base, suture, and apical margins narrowly reddish brown, the lateral margins very narrowly reddish. Abdomen impunctate.

St. Vincent (H. H. Smith). Type in the British Museum.

\section{S T ENINI.}

\section{Stenus (Mesostenus) lucens, sp. n.}

(croceipes, $\mathrm{Fvl}$., in litt.).

Narrow, elongate, shining black; elytra and abdomen very sparingly punctured. Antennæ and legs reddish testaceous, the club of the former infuscate.

Length $3.5 \mathrm{~mm}$.

This species, by its very smooth polished surface, recalls the genus Megalops.

Head, with eyes, broader than the elytra, with rather broad, raised, almost impunctate, central space; the rest of the surface with moderately large, not very close puncturation; the central space and the surface between the punctures smooth and polished without trace of ground-sculpture, glabrous; labrum black. Antennæ rather long and slender, second joint shorter than the first, third much more slender than the second and nearly double its length, fourth a little shorter than third, fifth as long as fourth, sixth a little shorter than fifth, seventh a little shorter than sixth ; eighth about half the length of seventh, longer than broad; ninth and tenth of equal length, as long as, but stouter than, seventh; eleventh oval, pointed. Thorax widest at the middle, scarcely longer than its greatest width, equally narrowed in front and behind, impressed on either side at the widest part; puncturation much finer and more sparing than on the head, the interspaces smooth and polished, glabrous. Fourth tarsal joints deeply bilobed, the hind tarsi long and slender. Scutellum triangular with large puncture at apex, coriaceous. Elytra shorter than the thorax, transverse, with distinct humeral callus and an impression internal to the latter; disc impressed, puncturation fine and scattered as on thorax, interspaces smooth, polished, glabrous. Abdomen margined, gradually narrowed to the apex, with a few scattered punctures at the bases of the segments; the rest of the surface almost impunctate, pubescence scanty. 
o . Eighth dorsal plate with horseshoe-shaped emargination, fourth and fifth ventral plates impressed in the middle, sixth ventral plate with a narrow, rather deep, triangular excision.

Grenada (H. H. Smith). Type in the British Museum.

P I N O P H I L I.

12. Pinophilus vermiformis, sp. n.

(Fauvel, in litt.)

Head and elytra reddish brown; thorax and abdomen pitchy brown, the posterior margins of the segments and apex of the latter reddish. Antennæ, mouth-parts, and legs pale yellow.

Length $6.5 \mathrm{~mm}$.

Of about the size and build of $P$. debilis, Shp., but easily distinguished by being less shining and more pubescent, with shorter thorax, more sparingly punctured head, much more coarsely and sparingly punctured abdomen, and with red elytra.

Head large, transverse, with the eyes nearly as broad as the thorax at the anterior angles; eyes large, temples scarcely visible; front with an obsolete puncture on each side of the middle line behind the labrum; a row of four or five moderately large punctures on each side, converging towards the vertex, and two or three more or less obsolete punctures above and behind the eyes; no visible groundsculpture. Antennæ filiform, pilose ; first and second joints stout, elongate; second shorter and not so thick as first; third to seventh distinctly longer than broad, club-shaped; eighth and ninth a little longer than broad; tenth and eleventh moniliform. Thorax a little broader than long, a little wider at the anterior angles, narrowed in a straight line to the posterior angles, which are obtuse; truncate anteriorly with rounded anterior angles; disc with smooth impunctate line; the rest of the surface covered with pretty ciose, moderately coarse, umbilicate puncturation ; pubescence rather long and scanty. Elytra as wide as the thorax at the anterior angles and a third longer, distinctly longer than broad, coarsely and closely punctured, much more closely and coarsely than the thorax; pubescence rather long, scanty. Abdomen gradually but strongly attenuated posteriorly ; the first two visible segments pretty closely and moderately coarsely punctured, the following gradually less closely and more finely; pubescence rather long, not thick.

Mustique Island, Grenadines $(H . H$. Smith). Type in British Museum. 
PR O C I R R I.

\section{Palaminus insularis, sp. $\mathrm{n}$.}

A narrow, delicate, fragile species, shining testaceous; abdomen reddish. Legs and antennæ pale yellow, the last joint of the latter scarcely stouter than the penultimate.

Length $2.8 \mathrm{~mm}$.

Very close in general appearance, size, and colour to $P$. fragilis, Shp., but differs from it by the last joint of the antennæ not being thickened, the puncturation of the head and thorax more sparing, the sides of the latter more uniformly rounded towards the base, and the elytra rather shorter. From P. pallidus, Sahlb., it differs by its smaller size, the rounded sides of the thorax, and the less numerous but larger imbrications of abdominal segments; from $P$. variabilis, Er., by its fragile build, the eleventh joint of the antennæ not thickened, and the much less distinct puncturation of the elytra.

Head transverse with the eyes a little wider than the thorax, very sparingly and rather superficially punctured. Antennæ very slender; first and second joints of about equal length, a little thickened; third about as long as, but much more slender than, second; fourth to tenth longer than broad, gradually decreasing in length; eleventh a little longer, but not thicker, than tenth. Thorax transverse, narrower than the elytra; the sides gradually rounded and contracted to the base, widest at the junction of the middle and anterior thirds; disc with a trace posteriorly of an elevated line ; puncturation rather coarse, umbilicate, scattered; pubescence rather long and sparing. Elytra double the length of the thorax, distinctly longer than broad, puncturation fine and sparing, obsolescent posteriorly and externally ; pubescence rather long, coarse, and sparing. Abdomen with imbricate sculpture on the first four visible segments; pubescence scanty and coarse.

3. Last ventral plate a little produced and rather abruptly narrowed towards the end.

Jamaica, Hope Gardens district. Type in my collection.

\section{Palaminus coriaceus, sp. n.}

A narrow, fragile, delicate species varying from testaceous to reddish testaceous, not very shining; the head and thorax with very distinct coriaceous ground-sculpture. The last joint of the antennæ distinctly thicker than the penultimate.

Length 2.9 to $3.3 \mathrm{~mm}$.

Very similar to the preceding in build, but at once dis- 
tinguished by the ground-sculpture of the head and thorax, the thickened last joint of the antennæ, and the obsolete puncturation of the fore parts.

Head transverse, with the eyes broader than the thorax, sparingly and obsoletely punctured. Antennæ testaceous, of similar structure to the preceding, except for the eleventh joint, which is stouter and longer than the tenth. Thorax formed as in $P$. insularis, puncturation scanty and very obsolete. Elytra as in the preceding species and without visible ground-sculpture. Abdomen reddish with the usual imbricated sculpture and coarse pubescence.

๙. Last ventral plate gradually narrowed and produced.

Jamaica, Haiti. Type in my collection.

\section{P E D E R I N I.}

\section{Stilicopsis circumflexus, sp. $\mathrm{n}$.}

(Fauvel, in litt.)

Pitchy red, scarcely shining; antennæ, legs, apex of abdomen, and elytra testaceous, the latter with well-marked black lateral spot. Seventh abdominal segment furnished posteriorly with a narrow white membranous border.

Length $2 \cdot 8$ to $3 \mathrm{~mm}$.

Variety.-Entirely reddish testaceous with elytral spot illdefined. Type-form readily recognized by the coloration, but the variety very similar to $S$. hrevis, Shp., in general appearance, but differs by the rather na rower head, distinctly narrower thorax, and shorter elytra. Head large, suborbicular, as broad as the elytra. Eyes rather large, prominent; temples not quite so long as the diameter of the eyes, slightly convergent to the posterior angles, which are rounded ; puncturation close and umbilicate. Labrum produced in a median lobe in front, notched in the middle of the anterior margin, external to the lobe on either side with a short triangular tooth directed forwards and inwards. Antennæ as long as the head and thorax ; first joint elongate, rather stout, three times as long as the second; second narrower than the first, a little longer than broad, shorter than third; third to ninth longer than broad, gradually decreasing in length ; tenth about as long as broad; eleventh not so long as the two preceding together. Thorax a little transverse, narrower than the head and elytra, widest at the anterior angles which are obtusely rounded, narrowed to the posterior angles which are effaced; sides with two or three setæ; puncturation close and umbilicate. Elytra scarcely 
longer, but a little broader, than the thorax, transverse, pretty closely and distinctly punctured. Abdomen rather shining, finely but not densely punctured and pubescent.

б. Last ventral plate broadly and deeply emarginate, penultimate with broad shallow emargination.

Mustique Island, Grenadines (H.H. Smith). Type in the British Museum collection.

\section{Stilicopsis auripilis, sp. n.}

(Fauvel, in litt.)

Reddish testaceous; elytra, antennæ, and legs yellow. Seventh dorsal abdominal segment not furnished with a membrane at the posterior border.

Length $2 \cdot 8$ to $3 \mathrm{~mm}$.

Very similar to the paler forms of the preceding with illdefined elytral spot, and it will be sufficient to indicate the differential characters, which are the absence of a membrane on the seventh dorsal segment and the thicker pubescence of the abdomen.

ऽ. Characters as in preceding.

Grenada (H. H. Smith). Type in the British Museum collection.

\section{Stamnoderus bernhaueri, sp. n.}

Reddish testaceous; elytra convex, not widened behind, yellow. Front of head and thorax with rather coarse rugulose sculpture.

Length $4 \mathrm{~mm}$.

Somewhat resembling S. championi, Shp., but smaller; the sculpture of the head and thorax more distinct; puncturation of elytra finer and the abdomen more closely and finely punctured and pubescent.

Head large, longer than broad, convex behind, depressed and produced in front of the eyes, which are large and prominent ; temples rounded ; labrum produced and truncate in the middle; sculpture close, rugulose in front of eyes, obsolete on vertex. Antennæ yellow, long and slender ; first joint elongate, stout; second about half as long as first, slender ; third about as long as first ; fourth to tenth considerably longer than broad, gradually decreasing in length; eleventh as long as, but stouter than, tenth. Thorax narrower than the head, a little longer than broad, flask-shaped, much narrower in front, dilated and rounded at the sides, which are furnished with a long seta, closely and rugosely 
sculptured, impressed on either side behind the widest part; disc with a fine median raised line. Elytra as long as the thorax, as broad as the head and a little longer than broad, a little rounded at the sides, pretty closely and moderately finely punctured; pubescence scanty. Abdomen with rather close aciculate puncturation and moderately pubescent.

3. First joint of posterior tarsi long and thick; sixth ventral plate rather broadly and moderately deeply emarginate ; fifth ventral plate with a shallow emargination.

Jamaica (Hope River district). Type in my collection.

\section{Stamnoderus dissimilis, sp. n.}

Entirely reddish testaceous; elytra depressed on the disc, widened behind. Front of head and thorax rather coarsely and rugulosely sculptured.

Length $5 \mathrm{~mm}$.

Somewhat resembling $S$. gracilis, Shp., in facies, the elytra being narrow at the shoulders, " idened behind, and depressed on the disc. The colour is, however, more reddish; the head broader and much more finely, closely, and distinctly sculptured; the thorax broader and more finely sculptured; the elytra more finely punctured, and the abdomen more closely and finely punctured. From S. labeo, Er., it differs by its rather larger and more robust build, much more coarsely sculptured head, broader and more distinctly sculptured thorax with much less distinct lateral impressions, and the more coarsely punctured elytra. From S. bernhaueri it differs by the broader thorax with well-marked basal impression and a smooth shining space on either side between this and the lateral impression, by the shape of the elytra, the much finer and scarcely aciculate puncturation of the abdomen, and the much longer second joint of the antennæ.

Head large, convex behind, produced and depressed in front of the eyes, which are large and prominent, posterior angles rounded; closely and rugosely sculptured in front of the level of the eyes, scarcely perceptibly punctured behind; foveolate on either side between the eyes. Antennæ yellow, long, slender ; first joint elongate, second much shorter than first, third much longer than second; fourth to seventh of about equal length, much longer than broad; eighth to tenth longer than broad, gradually decreasing in length; eleventh oblongovate, longer than tenth. Thorax a little narrower than the head, flask-shaped, rounded and dilated in the middle, strongly narrowed in front, less strongly narrowed behind, distinctly impressed at the base before the scutellum and on 
either side just behind the greatest width, finely carinate in the middle line, closely and rugosely sculptured except for a smooth space on either side between the basal and lateral impressions. Elytra a little widened posteriorly, the greatest width equalling that of the thorax, scarcely as long as the latter ; shoulders oblique, depressed on the disc, pretty closely and distinctly punctured. Abdomen dirty testaceous, paler at the apex, closely and finely punctured. Legs pale yellow. Jamaica (Hope River district). A single female.

Type in my collection.

\section{Stamnoderus upicalis, sp. n.}

Pale testaceous yellow, shining; base and sides of elytra more or less infuscate; abdomen blackish with yellow apex. Head and thorax scarcely perceptibly sculptured.

Length $2 \cdot 8$ to $3 \mathrm{~mm}$.

A small delicate species, not likely to be confused with any other at present known.

Head large, convex behind, produced and depressed in front of the level of the eyes, which are large and prominent, with a small fovea on either side and a few very obsolete punctures ; temples completely rounded. Antennæ slender with all the joints longer than broad, second shorter than the first and third. Thorax narrower than the head and elytra, flask-shaped, rounded and dilated at the sides, strongly narrowed in front, less strongly behind, narrowly impressed on either side behind the widest part, sparingly and obsoletely punctured, with trace of median line. Elytra a little longer than the thorax, longer than broad, moderately closely and finely punctured, more obsoletely behind. Abdomen exceedingly finely and rather closely punctured, finely pubescent.

Jamaica (Hope River district). Five females.

Type in my collection.

\section{Stamnoderus varians, sp. n.}

(Fauvel, in litt.)

Black; apical margin of elytra and apex of abdomen testaceous. Head and thorax closely and rugosely sculptured: elytra moderately coarsely and closely punctured.

Length 3 to $3.5 \mathrm{~mm}$.

Var. $a$. Head and thorax ferruginous.

Var. $b$. Head, thorax, and elytra ferruginous, the latter more or less infuscate at the base and sides.

Var. c. Entirely reddish testaceous. 
Shape of head as in preceding, foveolate on either side between the eyes, rugulosely sculptured, except posteriorly. Antennæ testaceous, of similar structure to the preceding. Thorax a little narrower than the head and elytra, longer than broad, flask-shaped, impressed on either side behind the widest part; disc with fine smooth carina, the rest of the surface with rugulose umbilicate sculpture. Elytra as long as, or a little longer than, the thorax, as long as broad, moderately coarsely and closely punctured. Abdomen finely and sparingly punctured and pubescent.

$\delta$. First joint of posterior tarsi thickened, sixth ventral plate with a shallow emargination.

Grenada, St. Vincent (H. H. Smith). Type in the British Museum.

\section{Echiaster waterhousei, sp. n.}

(Fauvel, in litt.)

Ferruginous, dull; elytra testaceous with apical half black.

Length $2.3 \mathrm{~mm}$.

In coloration nearest to E. filum, Shp., and E. curtus, Shp. : from the first very distinct by the much shorter and broader thorax, and less elongated and attenuated build; from the last by the much narrower and less robust build, smaller head, narrower thorax, with the longitudinal impressions and median elevated line much less distinct, and the finer sculpture.

Head subquadrate, longer than broad, dull, ferruginous, posterior angles rounded; eyes rather large, their diameter less than the length of the temples; puncturation close, rugose, umbilicate. Antennæ testaceous, short; first joint much dilated; second transversely oval ; third globose, much smaller than second; fourth to tenth transverse, gradually increasing in breadth, the penultimate about three times as broad as long; eleventh not quite so long as the two preceding together. Thorax narrower than the head and the elytra, longer than broad, oval-oblong, widest at the anterior angles, which are rounded, narrowed in front and behind, with the posterior angles obtuse ; disc posteriorly with a longitudinal impression on either side of the middle line, which by contrast appears more or less elevated; sculpture as on head. Legs testaceous. Elytra longer than the thorax, longer than broad, the basal half testaceous, the apical half black, usually sharply defined, but sometimes only represented by a fuscous cloud. Sculpture close, rugose, with short pubescence. 
Abdomen gradually narrowed behind, reddish testaceous, a little infuscate before the apex ; rather closely and coarsely punctured and pubescent at the base, more sparingly posteriorly.

Grenada (H. H. Smith). Type in the British Museum.

\section{Echiaster buphthalmus, sp. n.}

Reddish testaceous, dull; elytra yellow with the apical third sharply black; apex of abdomen blackish. Antennæ and legs testaceous.

Length $3 \mathrm{~mm}$.

Differs from the preceding by the larger head, larger eyes, shorter temples, longer narrower thorax, coloration of the elytra, and more pointed abdomen; from E. filum, Shp., by the broader head, larger eyes, shorter temples, broader even thorax without central ridge or longitudinal impressions, and longer elytra with only the apical third black.

Head large, nearly orbicular, much wider than the thorax, posterior angles rounded; temples much shorter than the eyes, which are large ; puncturation dense, umbilicate. Antennæ short ; first joint elongate, stout ; second oval, third longer than broad, fourth and fifth about as long as broad, sixth to tenth transverse. Thorax oval-oblong, even, without central ridge or impressions, anterior angles completely rounded, the posterior obtuse; sculpture as on head. Elytra broader than the thorax, longer than broad, a little longer than the thorax, yellow, with the apical third sharply black, rugosely punctured. Abdomen distinctly narrowed behind, closely punctured, and shortly pubescent; apex black.

Mustique Island, Grenadines (H.H. Smith), St. Vincent. Type in my collection.

\section{Echiaster sharpi, sp. n.}

Narrow, elongate, dull ; head and thorax ferruginous, the former orbicular. Elytra black, obscurely lighter at the shouldèrs and longer than broad. Abdomen black. Antennæ and legs testaceous.

Length $3 \mathrm{~mm}$.

Facies of E. orbifer, Shp., but colour entirely different, the thorax wider at the anterior angles and with a raised central line, and the elytra shorter.

Head large, orbicular; eyes large, their diameter much greater than the length of the temples; sculpture close, rugose, umbilicate. Antenrix reddish testaceous, of similar structure to the preceding. Thorax narrower than the head, Ann. \& Mag. N. Hist. Ser. 8. Vol. xii. 
distinctly longer than broad, oval-oblong, carinate in centre ; anterior angles rounded, posterior obtuse ; sculpture as on head. Elytra black, lighter at the shoulders, distinctly longer than broad, and little longer than the thorax, closely and rugosely punctured. Abdomen black, narrower at apex, which is obscurely lighter, closely punctured, and shortly pubescent.

Jamaica (Hope River district). Type in my collection.

\section{Echiaster distinctus, sp. n.}

Narrow, elongate, dull, pitchy black; head subquadrate ; elytra obscurely lighter at the shoulders, as broad as long. Antennæ and legs testaceous.

Length $2.8 \mathrm{~mm}$.

Facies somewhat similar to E. minutus, Shp., but differs by the coloration, more robust build, longer thorax, and shorter elytra. From E. sharpi it is easily distinguished by the differently shaped head, obviously shorter and broader thorax, and shorter elytra.

Head large, subquadrate, longer than broad, posterior angles rounded at the apex; eyes rather small ; temples large, their length greater than the diameter of the eyes ; puncturation close, rugose, umbilicate. Antennæ as in preceding. Thorax narrower than the head and elytra, broadest at the anterior angles which are rounded, the posterior angles obtuse, scarcely longer than broad, carinate posteriorly in the middle line ; sculpture as on head. Elytra as long as broad, black, reddish testaceous at the shoulders, closely and rugosely punctured. Abdomen pitchy black, ferruginous at apex, closely punctured and shortly pubescent.

Jamaica (Wag Water River). 'Type in my collection.

25. Echiaster impressicollis, sp. n.

(Fauvel, in litt.)

Narrow, elongate, dull, strongly narrowed posteriorly, dirty brownish testaceous; abdomen black at apex. Antennæ and legs testaceous.

Length $4 \mathrm{~mm}$.

In size, general appearance, and coloration (excepting the elytra, which are of same colour as the head and thorax) resembles E. signatus, Shp. ; but differs from this species by the shorter, broader, less attenuated head, shorter, uniformly coloured, and much more coarsely sculptured elytra.

Head longer than broad, oval, gradually rounded and contracted behind the eyes, without trace of posterior angles, 
coarsely and rugosely punctured. Antennæ as long as the head ; first joint elongate, stout; second globose ; third and fourth of equal length, much longer than broad; fifth and sixth of equal length, longer than broad, but much shorter than third and fourth; seventh to tenth transverse, gradually increasing in breadth; eleventh about as long as the two preceding together, acuminate; the last five joints pilose. Thorax long and narrow, twice as long as broad, widest at the middle, gradually narrowed in front and behind with all the angles obliterated, closely and rugosely sculptured. Elytra not longer than the thorax, very coarsely, but not very closely punctured, with a coar:e pubescence; intervals between the punctures smooth and shining. Abdomen strongly pointed, the first four visible segments very coarsely punctured and pubescent, the intervals shining and smooth, the last two segments very finely punctured and pubescent,
shining, blackish.

Balthazar, Grenada (H. H. Smith). Type in the British
Museum.

\section{Monista personata, sp. n.}

(Fauvel, in litt.)

Ferruginous, rather shining; elytra lighter. Anterinæ and legs testaceous.

\section{Length $2.8 \mathrm{~mm}$.}

Size and build of $M$. plagiata, Shp., from which it differs by the uniformly coloured elytra, less shining appearance, and the remarkable depressions on the head in male.

Head large, orbiculate; labrum emarginate; eyes small; temples large : posterior angles completely effaced; puncturation scattered, large, superficial, umbilicate, and with a fine coriaceous ground-sculpture. Antennse pilose; first joint elongate, stout; second shorter than first and third, third and fourth longer than broad, fifth to seventh globose, eighth to tenth transverse; eleventh rather stout, scarcely as long as the ninth and tenth together. Thorax narrower than the head and elytra, a little longer than broad, oval, widest about the middle, with all the angles effaced, with sparing, superficial, umbilicate punctures and a fine wrinkled groundsculpture. Elytra longer than the thorax, longer than broad; puncturation fine and obsolete on a polished ground, sparingly pubescent. Abdomen finely and sparingly punctured and pubescent.

o. Vertex of head with a large, deep, semicircular im. pression on either side of middle line, which is reduced to 
a narrow carina separating the two impressions. Last ventral plate very feebly and broadly emarginate.

Grenada (H.H. Smith). Type in the British Museum collection.

\section{Stilicus jucundus, sp. n.}

(Fauvel, in litt.)

Bronze-black, rather dull; elytra shining, with the apical border narrowly testaceous. Antennæ and legs testaceous.

Length $4 \mathrm{~mm}$.

In general appearance and coloration very similar to S. muticus, Shp., but differs by the narrower and more coarsely punctured thorax, with broader smooth central line, much more coarsely punctured elytra, and the male characters.

Head large, transverse, with the eyes broader than the elytra; posterior angles completely rounded; eyes large; puncturation close, umbilicate. Labrum testaceous. Antennæ with first joint elongate, rather stout ; second shorter than first and third; fourth distinctly, fifth and sixth slightly, longer than broad; seventh to tenth about as long as broad; eleventh not so long as the two preceding together. Thorax a little longer than broad, widest at the anterior angles, which are rounded, considerably narrowed in front, a little rounded and gradually narrowed to the posterior angles, which are a little obtuse, narrower than the head and elytra; disc with a rather broad, smooth, central line in nearly the whole length; puncturation similar to, but rather coarser than, that of the head. Elytra a little longer than the thorax, as long as broad, coarsely but not closely punctured, with the apical margin narrowly, and the postero-external angles more broadly, testaceous, shining. Abdomen black, shining, pretty closely and finely punctured and pubescent.

Observe.-In some specimens a slight violet shade is noticeable.

$0^{n}$. Last ventral p'ate with deep triangular excision.

St. Vincent (H. H. Smith). Type in the British Museum colection.

\section{Stilicus agnatus, sp. n.}

(Fauvel, in litt.)

Black, a little shining. Elytra narrowly testaceous at apical margin. Antennæ and legs testaceous.

Length $4 \mathrm{~mm}$.

Very similar to the preceding, so that a detailed description is unnecessary. It differs by having the head and thorax 
more shining and rather more coarsely punctured, the anterior thoracic angles more distinct, and the less closely punctured and pubescent abdomen, and the male characters.

o. Last ventral plate with deep triangular excision, the penultimate impressed in the middle line and sinuate on either side.

Grenada (H. H. Smith). Type in the British Museum.

\section{Stilicus insularis, sp. n.}

Black, dull; elytra shining, unicolorous, obsoletely punctured. Antennæ (except last two or three joints) and legs pitch-brown.

Length $4 \mathrm{~mm}$.

Head large, transverse, with the eyes a little broader than the elytra, posterior angles rounded ; eyes large ; vertex with small, smooth, shining spot. Labrum and palpi pitch-black; puncturation close, umbilicate. Anteunæ pitch-black, with the last two or three joints testaceous ; first joint long, stout ; second shorter than first, about as long as third ; third and fourth a little longer than broad; fifth to tenth moniliform ; eleventh short, acuminate. Thorax as long as broad, narrower than the head and elytra, trapezoidal, widest at the anterior angles, which are distinct and obtuse, strongly narrowed in front, less strongly contracted in almost a straight line to the posterior angles, which are obtuse; disc with a smooth, shining, central space in its whole length; puncturation as on head. Legs pitchy brown; tarsi testaceous. Elytra about a third longer than the thorax, slightly longer than broad, shining black, with very fine sparing puncturation. Abdomen pretty finely and moderately closely punctured and pubescent.

б. Last ventral plate with semicircular emargination, penultimate with two small tubercles near the posterior margin, separated by a semicircular impression with the convexity forwards.

Jamaica (Chester Vale district). Type in my collection.

\section{Stilicus cupreus, sp. n.}

Head, thorax, and abdomen bronze-black with coppery reflex; elytra brown, shining, with distinct coppery reflex. Antennæ brown with base and apex lighter; legs pale testaceous ; tibiæ infuscate.

Length $4: 3 \mathrm{~mm}$.

Head transverse, posterior angles rounded, quite as broad 
as the elytra. Labrum and palpi dark brown. Antennæ with first two joints reddish brown, third to eighth dark brown, ninth to eleventh testaceous; first joint elongate, stout; second shorter than first and third; third to sixth longer than broad, gradually decreasing in length; seventh to tenth moniliform; eleventh short, oval. Puncturation close, umbilicate, with small, smooth, shining space on the vertex. Thorax trapezoidal, scarcely longer than the breadth at the anterior angles, which are distinct and obtuse, gradually narrowed in a straight line to the base, more strongly narrowed in front; disc with smooth central line throughout; puncturation as on head. Elytra distinctly longer than the thorax, longer than broad, with moderately coarse and rugulose puncturation. Abdomen shining, coppery bronze, closely and finely punctured and pubescent. Jamaica (Newcastle district, 3000 feet above sea-level). A single female. Type in my collection.

\section{Thinocharis fuscina, sp. n.}

(Fauvel, in litt.)

Ferruginous; head blackish, truncate posteriorly; elytra more or less infuscate on disc; head, thorax, and elytra closely and distinctly punctured.

Length 3 to $3.3 \mathrm{~mm}$.

Exceedingly close to $S$. densicollis, Shp., in general appearance and shape of head; but differs by the average smaller size, less robust build, narrower thorax, and the male characters.

Head transverse, quadrate, broader than the thorax, truncate posteriorly ; eyes rather large, their diameter equal to the length of the temples; posterior angles rectangular, pretty closely punctured, and finely wrinkled, sparingly pubescent, sides with well-marked setæ. Antennæ as long as the head and thorax, furnished with long hairs; first joint long and stout; second about balf the length of the first and less rhickened; third to tenth longer than broad, and scarcely differing in length and breadth, much more slender than second; eleventh elongate, acuminate. Thorax a little broader than long, broadest at the anterior angles, which are ohtusely rounded, gradually narrowed behind to the posterior angles which are effaced; puncturation fine, close, umbilicate; disc with smooth central line; sides setiferous. Elytra broader and distinctly longer than the thorax, longer than broad, testaceous, more or less infuscate on the disc, leaving the sides and apex clear; puncturation finer than 
that of the thorax, umbilicate, moderately pubescent. Abdomen pretty closely and finely punctured and pubescent throughout.

๙. Last dorsal plate deeply and semicircularly incised; fifth ventral plate with deep semicireular notch on either side of middle line, which forms a triangular lobe separating the notches; sixth ventral plate with a deep triangular notch.

Grenada (H. H. Smith). Type in British Museum.

\section{Thinocharis smithi, sp. n.}

(Fauvel, in litt.)

Entirely black, rather shining; head large, transverse; elytra not longer than the thorax. Antennæ and legs reddish testaceous.

Length $2.5 \mathrm{~mm}$.

Remarkable by its broad head, which is considerably wider than the thorax and elytra, and the shortness of the latter.

Head with eyes considerably broader than long; eyes very large, their diameter much greater than the length of the temples and occupying nearly all the side of the head; temples very small ; posterior angles rounded; puncturation moderate, pretty close, umbilicate. Antennæ reddish testaceous, pilose ; first joint rather long and stout ; second about half as long as first and about as thick; third to tenth longer than broad, gradually decreasing in length, the first of them about as long as, but much more slender than, second, the last of them a little longer than broad; eleventh oval, pointed. Thorax broader than the elytra, a little broader than long, broadest at the anterior angles, which are obtuse, gradually narrowed behind in a straight line to the posterior which are effaced; puncturation umbilicate, coarser and not so close as on the head; disc with smooth shining central line. Elytra as long as broad, slightly widened behind, narrower than, and about as long as, the thorax, with coarse scattered puncturation and coarse sparing pubescence. Abdomen moderately finely and closely punctured with rather fine pubescence.

๙. Fifth ventral plate broadly emarginate posteriorly, sixth ventral plate with triangular notch in the posterior margin.

Grenada (H. H. Smith). Type in the British Museum. 


\section{Ophiomedon anthracinus, sp. n.}

(Fauvel, in litt.)

Entirely black, dull. Antennæ black, with the apex of last joint yellowish. Legs dark brown.

Length $5 \cdot 5-6 \cdot 3 \mathrm{~mm}$.

Head square, as broad as the elytra, truncate posteriorly; eyes small, their diameter much less than the length of the temples, which are long and parallel; posterior angles right angles, only blunted at the extreme apex; mouth-parts brown. Antennæ long, rather slender, pilose; first joint stout, elongate ; second much shorter than first and third; third much shorter than first; fourth to tenth longer than broad, gradually decreasing in length; eleventh oval, pointed, longer than tenth; puncturation close, umbilicate, not very coarse. Thorax scarcely longer than broad, widest at the anterior angles, which are obtuse, gradually narrowed posteriorly in a straight line. Puncturation similar to, but rather finer than, that of the head; disc with a fine channel posteriorly. Elytra distinctly longer than the thorax, longer than broad, pretty closely and finely punctured. Abdomen closely and finely punctured.

б. Last ventral plate with a deep triangular excision; the penultimate rather deeply and broadly emarginate, the base of the emargination rounded, the angles produced a little backwards, and, together with the sides of the notch, turned and folded to form on either side a spoon-shaped structure with the concavity inwards.

St. Vincent (H. H. Smith). Type in the British Museum.

\section{Medon cingulatus, sp. n.}

(Fauvel, in litt.)

Pitch-brown or pitch-black, dull; apical third or half of the elytra, apex of abdomen, antenuæ, and legs reddish testaceous. Tarsi simple.

Length $3.5 \mathrm{~mm}$.

Size and build of $L$. infuscatus, readily distinguished by the much smaller eyes, the rectangular posterior angles of the head (which, with the thorax, is much more finely punctured), and the coloration of the elytra.

Head large, square, as broad as the thorax ; eyes moderate ; temples considerably longer than their diameter; base truncate, posterior angles rectangular; sculpture coriaceous, with very fine, obsolete, scattered punctures; sides with 
well-marked setæ. Antennæ with first joint long and rather stout; second, third, and fourth of equal length, each a little longer than broad; fifth and sixth moniliform ; seventh to ninth transverse, gradually increasing in width; tenth about as broad as long; eleventh oval, pointed; the first four joints setose, the rest pilose. Labrum bidentate, with small notch between the teeth. Thorax a little longer than broad, widest at the anterior angles, which are obtuse, gradually narrowed behind, with the posterior angles broadly rounded; centre of disc with trace of median line; sculpture coriaceous, with very fine, obsolete, scattered puncturation ; sides with well-marked setæ. Elytra longer than broad, longer than the thorax and scarcely narrower, the apical third or half reddish testaceous ; puncturation pretty close, fine, and aciculate, moderately closely pubescent. Abdomen closely punctured and pubescent throughout; apex reddish testaceous.

ช. Last ventral plate distinctly emarginate.

St. Vincent, Grenada (H. H. Smith). Type in the British Museum.

\section{Aderocharis conifer, sp. n.}

(Fauvel, in litl.)

Black, dull ; sides, postero-external angles and apical margins of the elytra, posterior margins of the dorsal abdominal segments, apex of the abdomen, antennæ, and legs reddish testaceous.

Length $6 \mathrm{~mm}$.

Somewhat resembling $A$. latro, Shp., but smaller, thorax narrower, elytra longer, and differently coloured.

Head large, quadrate, as broad as the elytra; eyes small, their diameter considerably less than the length of the temples, which are long and parallel; posterior angles right angles, just blunted at the extreme apex; vertex emarginate before the neck, and with a trace of fine line towards the front. Labrum, mandibles, and palpi red; puncturation very fine and close. Antennæ reddish, pilose; first joint long and stout; second much shorter than first; third longer than second, but shorter than first; fourth to tenth longer than broad, gradually decreasing in length; eleventh oval, pointed, not much longer than tenth. 'Thorax about as long as broad, narrower than the elytra, broadest at the anterior angles, which are obtuse, gradually narrowed in a straight line to the posterior angles, which are rounded; dise with a narrow smooth central line; the rest of the surface 
densely and finely punctured. Elytra longer than the thorax, longer than broad, pitchy, the sides broadly, the apex narrowly, reddish, densely finely, but rather roughly, punctured. Abdomen black, the posterior margins of the first four visible segments narrowly, the penultimate broadly, and the last entirely reddish testaceous, finely and densely punctured and pubescent throughout.

$\delta$. Fifth ventral plate produced in the middle into a triangular lamella, with emarginate apex and closely beset with black setæ, which bears near the base on either side a large, broad, smooth tooth; sixth ventral plate with broad deep emargination.

St. Vincent (H. H. Smith). Type in the British Museum.

\section{Aderocharis obscurior, sp. n.}

(Fauvel, in litt)

Black, dull; elytra reddish brown; posterior margins of the dorsal abdominal segments and apex obscurely lighter.

Length $6 \mathrm{~mm}$.

Very closely allied to the preceding, so that a detailed description is unnecessary, and from which it differs by the more uniform reddish-brown colour of the elytra and the more obscure coloration of the abdomen.

No sexual differences observed; all the specimens appear to be females.

Grenada (H. H. Smith). Type in the British Museum.

\section{Scopæeus angusticollis, sp. n.}

(Fauvel, in litt.)

Reddish brown, not very shining; abdomen lighter; antennæ, legs, posterior margins of the abdominal segments and apex testaceous.

Length $3.8 \mathrm{~mm}$.

Size and colour of S. ligulifer, Shp., but distinct by its longer head and thorax, longer and much more finely punctured elytra.

Head longer than broad, broader than the elytra; temples long, parallel; vertex emarginate posteriorly; posterior angles rounded; closely and finely punctured throughout. Antennæ with first joint rather long and stout; second to sixth longer than broad, gradually decreasing in length ; seventh to tenth globose; eleventh oval, pointed. Thorax narrower than the head, distinctly longer than broad, widest at the anterior angles, which are rounded but traceable, very 
slightly narrowed to the posterior angles; disc with a very fine median line posteriorly and obsolete impression on either side before the base; puncturation fine and close, much finer than on the head, sparingly pubescent. Elytra distinctly longer than the thorax, much longer than broad, finely and closely but less distinctly punctured than the thorax. Abdomen closely and finely punctured and pubescent.

ơ unknown.

Grenada (H. H. Smith). Type in the British Museum.

38. Scopceus auripilis, sp. n.

(Fauvel, in litt.)

Dull ; head and thorax ferruginous or black ; elytra black, with apical margin sharply testaceous; abdomen black, somewhat shining, the posterior third of seventh and posterior half of eighth dorsal plates sharply testaceous. Antennæ and legs testaceous. The whole insect rather thickly clothed with yellowish pubescence.

Length $3 \mathrm{~mm}$.

A species very distinct by its coloration and pubescence.

Head as broad as long, a little broader than the thorax at the anterior angles; temples parallel; vertex emarginate posteriorly; posterior angles right angles, only blunted at the extreme apex ; puncturation close, rugulose, umbilicate ; pubescence yellow, distinct. Antennæ with first joint elongate, stout; second and third of equal length ; fourth shorter than third, a little longer than broad; fifth to seventh globose, eighth to tenth transverse, eleventh shortly oval. Thorax scarcely longer than broad, widest at the anterior angles, which are obtuse, gradually narrowed behind to the posterior angles, which are rounded, more abruptly narrowed in front to the neck; disc with a very fine shining carinula behind, but without trace of basal foveæ. Puncturation and pubescence as on the head. Elytra slightly longer than the thorax, a little longer than broad, the apical margin distinctly testaceous, the shoulders sometimes obscurely lighter; puncturation close and rugulose, rather finer than that of the thorax, especially behind; pubescence distinct, yellow. Abdomen slightly widened behind, less dull than the fore parts, the posterior third of seventh and posterior half of eighth dorsal segment sharply testaceous, pretty closely and finely punctured, and with rather long yellow pubescence.

ơ unknown.

St. Vincent, Grenada (H. H. Smith). Type in the British Museum. 
39. Scopæus simplicicollis, sp. n.

(Fauvel, in litt.)

Narrow, elongate, scarcely shining; head ferruginous; thorax black; elytra and abdomen black, the apical border of the former and the posterior margins of the dorsal segments and apex of the latter narrowly reddish testaceous. Antennæ and legs reddish testaceous.

Length $2.3 \mathrm{~mm}$.

In size, and superficially, resembles S. umbra, Shp.; but differs from it by the darker coloration, broader, differently shaped head, much coarser puncturation of the fore parts, the absent or very obsolete basal foveæ of the thorax, and the male characters.

Head a little longer than broad, as broad as the elytra; temples very slightly dilated and feebly narrowed to the posterior angles, which are rounded, emarginate at the posterior border, closely and finely punctured, finely pubescent. Antennæ with first joint stout, elongate; second to sixth longer than broad, gradually decreasing in length; seventh to tenth globose; eleventh short, oval. Thorax narrower than the head, distinctly longer than broad, broadest at the anterior angles, which are rounded, abruptly narrowed in front, gradually narrowed behind to the rounded posterior angles ; disc with a very fine median line throughout the entire length, but without or with very obsolete basal foveæ; puncturation close, a little coarser than on the head. Posterior tarsi short. Elytra a little longer than the thorax, distinctly longer than broad, similarly punctured to the thorax, finely pubescent. Abdomen very finely and moderately closely punctured and pubescent.

$\delta$. Sixth ventral plate with a broad semicircular emargination of the posterior border ; fifth ventral plate with a broad, very feeble emargination.

St. Vincent, Grenada (H. H. Smith). Type in the British Museum.

\section{Scopæus umbra, Shp.}

This species was described in the "Biologia CentraliAmericana' (i. 2, p. 544) from female specimens, the male being then unknown. This sex has the sixth ventral plate narrowly and deeply excised in the middle line ; fifth ventral plate longitudinally impressed in the middle, the impression furnished with short black setæ.

It is found in Grenada (H. H. Smith), Haiti, and Jamaica. 


\section{Scopeus marginatus, sp. n.}

Black, not very shining (greasy lustre only), the posterior margin of the elytra narrowly but brightly reddish testaceous; legs and last six joints of the antennæ reddish testaccous; the basal half infuscate.

Length $3 \mathrm{~mm}$.

Size and build of S. ligulifer, Shp., from which it differs by the finer puncturation of the head and thorax, the coloration, and the male characters.

Head square, a little broader than the thorax; the temples parallel ; the posterior angles bluntly rectangular, the posterior margin slightly emarginate. Antennæ with first seven joints longer than broad, gradually decreasing in length, the last of them slightly oval ; eighth to tenth as long as broad; eleventh oval, pointed; puncturation very fine and close; pubescence very fine and sparing. The thorax a little longer than the greatest width, which is at the anterior angles, which are obtuse but distinct; the disc without basal impressions and with a feeble trace of central line in front only; puncturation very fine and close; pubescence fine. Elytra a little longer than the thorax, longer than broad, firiely and closely punctured, finely pubescent. Abdomen black, extreme apex brownish ; puncturation and pubescence fine and close throughout. Posterior tarsi short.

б. Sixth ventral plate with deep triangular excision of the posterior margin, fifth slightly emarginate and feebly impressed, second and third with slightly curved, transverse, impressed line before the posterior borders, the concavity backwards.

Jamaica. Type in my collection.

\section{Scopeus antennalis, sp. n.}

Black, not very shining (greasy lustre only); elytra uniform dark brown; legs and last joints of the antennæ reddish testaceous.

Length $3.5 \mathrm{~mm}$.

This species is so similar to the preceding that a detailed description is unnecessary. It differs from it by larger and more robust build, the thorax more finely punctured, the antennæ are longer, all the joints longer than broad and the first five or six infuscate, the elytra unicolorous, the abdomen more densely pubescent, and the male characters.

б. Sixth ventral plate with deep triangular excisions at the posterior margin ; fifth ventral plate feebly emarginate.

Haiti. Type in my collection. 


\section{Micranops, gen. nov.}

Body elongate, apterous. Head oval-oblong, a little broader than the thorax, longer than broad, emarginate posteriorly, the neck about one-third the breadth of the head. Eyes wanting, their position marked by a small, round, whitish depression. Labrum transverse, bidentate, the teeth separated by a narrow triangular notch, setose. Mandibles falciform, with three blunt teeth about the middle. Maxillæ with the inner lobe ciliate internally, the outer ciliate at apex. Maxillary palpi of normal length; first joint very small; second elongate, about the length of third, the latter thickened towards the apex; fourth minute, subulate. Labium transverse. Tongue small, acuminate; paraglossæ of similar size and shape. Labial palpi with first and second joints cylindrical ; second a little longer than first; third slender, pointed. Gular sutures diverging in front and behind, most approximate about the middle. Antennæ filiform, straight. Thorax oblong, as wide as the elytra, with the angles rounded. Scutellum small, triangular. Elytra shorter than the thorax, transverse. Abdomen bordered, slightly widened before the apex, seventh dorsal segment without a membrane at the posterior border; first ventral plate furnished with a short keel at the base ; anal styles not exposed. Legs rather short, thighs stout, anterior tibiæ excavate internally. Tarsi five-jointed, the anterior (at least in ơ ) dilated, middle and posterior short, simple ; the first four joints subequal, fifth shorter than the first four united; claws simple. Tibiæ pubescent.

Stands near Lathrobium and Scopaus; from the first it differs in the bidentate labrum, the tridentate mandibles, pointed ligula, and structure of the posterior tarsi ; from Scopceus it differs by the bidentate labrum, simple ligula, and stout neck, but agrees with it in the structure of the posterior tarsi. It has the facies of a minute Lathrobium.

\section{Micranops brunneus, sp. n.}

Dark chestnut-brown, scarcely shining; head and thorax strongly coriaceous, with superficial scattered puncturation ; mouth-parts, antennæ, and legs testaceous.

Length $2 \cdot 3 \mathrm{~mm}$.

Head oval-oblong, longer than broad, emarginate posteriorly, posterior angles rounded. Eyes absent, their position marked by a round whitish depression. Antennæ testaceous; first joint stout, not quite so long as the three following 


\section{$2 \mathrm{BHL}$ Biodiversity Heritage Library}

1913. "Descriptions of new species of Staphylinidae from the West Indies." The Annals and magazine of natural history; zoology, botany, and geology 12, 321-350. https://doi.org/10.1080/00222931308693407.

View This Item Online: https://www.biodiversitylibrary.org/item/71910

DOI: https://doi.org/10.1080/00222931308693407

Permalink: https://www.biodiversitylibrary.org/partpdf/60621

\section{Holding Institution}

University of Toronto - Gerstein Science Information Centre

\section{Sponsored by}

University of Toronto

\section{Copyright \& Reuse}

Copyright Status: NOT_IN_COPYRIGHT

This document was created from content at the Biodiversity Heritage Library, the world's largest open access digital library for biodiversity literature and archives. Visit BHL at https://www.biodiversitylibrary.org. 